\title{
DEMOGRAPHY OF Astrocaryum malybo H.Karst. (ARECACEAE) IN COLOMBIA, RECOMMENDATIONS FOR ITS MANAGEMENT AND CONSERVATION
}

\author{
Demografía de Astrocaryum malybo H.Karst. (ARECACEAE) en Colombia, \\ recomendaciones para su manejo y conservación
}

\author{
Néstor García', Gloria Galeano ${ }^{\dagger} \&$ Rodrigo Bernal²
}

García, N., Galeano, G. \& Bernal, R. (2017) Demography of Astrocaryum malybo H.Karst. (Arecaceae) in Colombia, recommendations for its management and conservation. Colombia Forestal, 20(2), 107-117.

Recepción: 14 de agosto 2016

\begin{abstract}
The palm Astrocaryum malybo is an endangered species growing in forest remnants in the Caribbean lowlands of Colombia, where its spear leaves provide fiber for a flourishing artisanal activity. We studied the palm's population structure and dynamics near the town of Chimichagua, Cesar, in order to provide ecological information required for its management and conservation. We modeled population growth and fiber production in the next 20 years under different management scenarios using Integral Projection Models. Although there was a low proportion of seedlings and population structure was variable, the population would grow for the next 20 years, with an annual growth rate of $7.1 \%$, yielding ca. 35 spear leaves/ha/year for artisanal activity. Simulations of the model show that the population is susceptible to alterations that affect the survival of individuals; removal of as few as 34 palms of any size per ha/year would cause the population to decrease, and spear leaf production will decline accordingly. Conversely, any increase in seedling growth or survival would lead to population growth. If properly managed, A.
\end{abstract}

Aprobación: 22 de mayo 2017

malybo is a key species for conservation of the dry forest relicts in the Caribbean lowlands of Colombia. Keywords: Arecaceae, handicraft, Integral Projection Model, NTFP, plant fibers.

\section{Resumen}

La palma Astrocaryum malybo es una especie en peligro que crece en relictos de bosque en las tierras bajas del Caribe colombiano, donde sus cogoIlos suministran fibra para una próspera actividad artesanal. Se estudiaron su estructura y dinámica poblacional en Chimichagua, Cesar, con el fin de suministrar información ecológica para su manejo y conservación. Se modeló el crecimiento poblacional y la producción de fibra durante los próximos 20 años bajo diferentes escenarios de manejo, usando modelos de Proyección Integral. Aunque se encontró una baja proporción de plántulas y variaciones en la estructura poblacional, la población tenderá a crecer en los próximo 20 años, con una tasa anual de $7.1 \%$, suministrando cerca de 35 cogollos/ha/ año para la actividad artesanal. La modelación de escenarios muestra que la población es susceptible

1 Departamento de Biología, Facultad de Ciencias, Pontificia Universidad Javeriana. Bogotá, Colombia. nestor.garcia@javeriana.edu.co. Corresponding author.

2 Instituto de Ciencias Naturales, Universidad Nacional de Colombia, Apartado 7495. Bogotá, Colombia. rgbernalg@gmail.com 
a alteraciones que afecten la supervivencia de los individuos; con la eliminación de solo 34 palmas de cualquier tamaño por ha/año, la población tenderá a decrecer y como consecuencia la producción de cogollos decaerá. En contraste, cualquier aumento en la supervivencia o el crecimiento de las plántulas
Ilevaría a un crecimiento de la población. Si se maneja adecuadamente, A. malybo es una especie clave para la conservación de los relictos de bosque seco en el Caribe colombiano.

Palabras clave: Arecaceae, artesanía, fibras vegetales, Modelo de Proyección Integral, PFNM.

\section{INTRODUCTION}

Astrocaryum malybo, locally known as palma estera, is an acaulescent spiny palm endemic to the warm lowlands of northern Colombia, where it forms small populations in dry or wet forest relicts (Galeano \& Bernal, 2010). These populations have decreased more than $50 \%$ during the past decades, due to forest fragmentation or total deforestation, for establishing crops or pastures. As a result, this species is now categorized as Endangered ( $\mathrm{Ga}$ leano \& Bernal, 2005).

In the area surrounding the Zapatosa lagoon complex, in the departments of Cesar and Magdalena, remnant populations of $A$. malybo are the base of a flourishing handicraft activity upon which many households rely (Barrera et al., 2007; García et al., 2011; García, 2013). This activity is based on the harvest of leaflets from unexpanded leaves, which provide a fiber used for weaving mats and other products (Linares et al., 2008; García et al., 2011; García, 2013). Because of its subterranean stem, access to the unexpanded leaves is easy, and harvesters do not cut down the palms, as is done with other fiber-producing Astrocaryum species (García et al., 2013; García et al., 2015). Besides this, leaf harvest involves other actions aimed to reduce damage to the harvested leaves, and, as a result, local management is considered sustainable (García et al., 2011; García, 2013).

Although leaf harvest probably does affect the development of individual palms to some extent, overall impact is minimal, compared to the wholesale devastation of populations resulting from forest clearing for agriculture or cattle ranching (Barrera et al., 2007; García et al., 2011). Landowners prefer to eradicate the palms, due to the potential harm inflicted by the long spines, and the purported annoyances caused by intruding harvesters. Even in the forest fragments surviving along creeks, palms suffer damages from cattle, which wander freely and tread on seedlings. Yet, these forest fragments are the only areas where palm populations regenerate (García, 2013).

In order to provide ecological information required for management and conservation of $A$. malybo in this region, we studied its population structure and transient dynamics in forest fragments near the town of Chimichagua. In particular, we addressed the following questions: What is the population structure and density of $A$. malybo in these fragments? How is the demographic behavior under these conditions? How would population growth and fiber production behave in the next 20 years under different management scenarios?

\section{MATERIALS AND METHODS}

\section{Study species}

Astrocaryum malybo is a solitary palm with underground stem, or rarely up to $3 \mathrm{~m}$ tall, covered with black spines up to $10 \mathrm{~cm}$ long. An adult individual has 15-20 leaves up to 4.5-6 m long, densely armed with dark brown to black, flattened spines up to $20 \mathrm{~cm}$ long. Flowers are arranged in an erect, branched inflorescence up $1.4 \mathrm{~m}$ long; fruits are yellowish when immature, becoming violet or almost black when ripe (Galeano \& Bernal, 2010). The 
species is endemic to Colombia, where it grows in wet to moderately dry lowland forests in the Magdalena River basin, and around the northern end of the Andes, west to the northern Pacific Coast (Galeano \& Bernal, 2010).

\section{Study area}

Chimichagua is located in the southern department of Cesar ( $9^{\circ} 15^{\prime} 19.3$ "N, 73 48' 51.9" W), in an area classified as tropical dry forest, although most of the former forest cover has now disappeared. Average temperature is $27^{\circ} \mathrm{C}$ and average annual rainfall is $2448 \mathrm{~mm}$; September and October are the rainiest months, with an average of 391 $\mathrm{mm} / \mathrm{month}$, while the driest season spans from December to March, with an average of $54 \mathrm{~mm} / \mathrm{mon}$ th (Ideam, 2015).

Natural vegetation in the region has undergone a severe transformation into cattle pastures or subsistence crops (Estupiñán-González et al., 2011). The former dry forest is now represented by smaII strips of secondary vegetation along waterways, and is dominated by trees as Spondias mombim L. and the palms Attalea butyracea (Mutis ex L.f.) Wess.Boer, Elaeis oleifera (Kunth) Cortés and Astrocaryum malybo. These forest relicts are within private land and are subjected to permanent disturbance resulting from cattle, fires, or the extraction of firewood, timber, fibers or other forest products useful to local people.

\section{Study design and data collection}

We characterized population structure of A. malybo in eight $20 \times 50 \mathrm{~m}$ plots established in six secondary forest remnants near Chimichagua (table 1). The relics were selected with the help of artisans, which are also involved in leaf harvest. We censused all individuals in each plot, and recorded for each the number of leaves and the number of main veins in the youngest leaf. Since individuals of this species usually do not have an aerial stem, we used the number of main veins as the state variable related to size, as often used in acaulescent palms (Galeano et al., 2010). The main veins were always counted on the right side of the youngest expanded leaf.

We studied population dynamics in a 1.5 ha forest remnant located on the banks of a creek in finca La Cabaña (9 16' 19.6" N, 73 51' 15.9" W), where we tagged and censused 361 individuals of A. malybo between July 2012 and July 2013 (195 seedlings, 64 juveniles and 102 adults). We selected this forest remnant because it harbored the largest population of the species in the region. Thirty-seven adult palms at this site had evidence of leaf harvest. We marked the youngest expanded leaf in each palm and counted the number of main veins on its right side; in the second census (July 2013), we measured annual leaf production. We then estimated age of the individuals by combining number of veins, annual leaf production rate, and

Table 1. Description of plots used for determining the population structure of Astrocaryum malybo near Chimichagua, Cesar, in northern Colombia.

\begin{tabular}{ccclcc}
\hline Plot & Location & Coordinates (N-W) & \multicolumn{1}{c}{ Habitat } & $\begin{array}{c}\text { Canopy } \\
\text { cover }\end{array}$ & $\begin{array}{c}\text { Number of palms showing } \\
\text { evidence of leaf harvest }\end{array}$ \\
\hline 1 & Relic 1 & $9^{\circ} 14^{\prime} 16,2^{\prime \prime}-73^{\circ} 51^{\prime} 27,3^{\prime \prime}$ & Along creek & Open & 3 \\
2 & Relic 2 & $9^{\circ} 14^{\prime} 20,0^{\prime \prime}-73^{\circ} 51^{\prime} 23,7^{\prime \prime}$ & Along creek & Open & 7 \\
3 & Relic 3 & $9^{\circ} 14^{\prime} 21,5^{\prime \prime}-73^{\circ} 51^{\prime} 20^{\prime \prime}$ & Isolated relic in pasture & Closed & 3 \\
4 & Relic 3 & - & Isolated relic in pasture & Closed & 8 \\
5 & Relic 4 & $9^{\circ} 16^{\prime} 27,5^{\prime \prime}-73^{\circ} 51^{\prime} 10,4^{\prime \prime}$ & Along creek & Open & 3 \\
6 & Relic 5 & $9^{\circ} 16^{\prime} 20,8^{\prime \prime}-73^{\circ} 51^{\prime} 16,5^{\prime \prime}$ & Along creek & Closed & 7 \\
7 & Relic 5 & $9^{\circ} 16^{\prime} 19,6^{\prime \prime}-73^{\circ} 51^{\prime} 15,9^{\prime \prime}$ & Along creek & Closed & 9 \\
8 & Relic 6 & $9^{\circ} 15^{\prime} 13,3^{\prime \prime}-73^{\circ} 51^{\prime} 15,8^{\prime \prime}$ & Along creek & Open & 1 \\
\hline
\end{tabular}


average increase in vein number from one leaf to the next. We recorded the number and stage of reproductive structures in all adult palms.

\section{Vital rates}

We used regression models for relating stem length with vital rates. We studied growth $g(x, y)$ through linear regression models that related initial size $(x)$ to final size $(y)$. Survival $s(x)$ was studied through logistic regression models that related initial size $(x)$ to survival probability. For reproduction $f 2(x, y)$ we used logistic regression models relating initial size $(x)$ with the probability of having offspring of size $y$.

\section{Integral Projection Models (IPM)}

Because the studied population was small, especially for some size classes, we decided to use IPM for the demographic analysis, since that method is suitable for relatively small datasets, explicitly incorporates variation in growth rate between individuals and is very suitable for trees and palms (Zuidema et al., 2010). IPMs are used to describe changes, over a discrete period, in a population whose structure is characterized by a continuous or semi-continuous variable, or by a combination of discrete and continuous variables (Easterling et al., 2000; Metcalf et al., 2014). The initial stage of the population is described by a probability density function (distribution function), $n(x, t)$, which represents the proportion of individuals of size $x$ at time $t$. Thus, the model for knowing the proportion of individuals of size $y$ at time $t+1$, i.e., for describing population change after a discrete period of time, is defined by

$$
\begin{aligned}
n(y, t+1) & =\int_{\Omega}[p(x, y)+f(x, y)] n(x, t) d x \\
& =\int_{\Omega} k(y, x) n(x, t) d x
\end{aligned}
$$

where $k(y, x)$ represents all transition probabilities of an individual of size $x$ at time $t$ into an individual of size $y$ at time $t+1$, including new recruits. This function, called kernel, is integrated over a set of all size possibilities $(\Omega)$, and is made up of two components -a survival-growth function $p(x, y)$, and a fecundity function $f(x, y)$. The fecundity function $f(x, y)$ is positive for large individuals at time $t$ (parents, $x$ ) and small individuals at time $t+1$ (offspring, $y$ ), and it is zero for all others; the function $p(x, y)$ incorporates growth and survival of all individuals (Easterling et al., 2000).

The survival-growth and the fecundity functions are based on the regression models that describe the relations between size and vital rates. The survival-growth function is made up of two components:

$$
p(x, y)=s(x) g(x, y)
$$

The first one represents the survival probability of an individual of size $x, s(x)$; and the second represents the growth probability from size $x$ to size $y, g(x, y)$. The fecundity function is also made up of two components:

$$
f(x, y)=f l(x) f 2(x, y)
$$

The first one represents the average number of offspring produced by an adult of size $x, f 1(x)$, which was estimated by relating number of reproductive individuals in two $50 \times 20 \mathrm{~m}$ plots in one year with the number of seedlings recruited by the next year. The second one represents the probability that a size $x$ adult produces offspring of size $y, f 2(x, y)$; an individual was considered adult if it could reproduce (Easterling et al., 2000).

The IPM was built based on regression models. The kernel $k(y, x)$ was discretized into a transition matrix using the midpoint rule proposed by Easterling et al. (2000). For this, we used 108 mesh points. Based on this transformation, the population dynamics of $A$. malybo was described as in standard matrix models: $n(t+1)=\mathrm{K} n(t)$. Transient 
population growth rate $\left(\lambda_{\mathrm{t}}\right)$ was calculated as in Groenendijk et al. (2012):

$$
\lambda_{20}=\sqrt[20]{n_{20} / n_{0}}
$$

where $n_{0}$ and $n_{20}$ represent population size at $t=0$ and $t=20$, respectively. We estimated 95\% confidence interval $(\mathrm{Cl})$ for lambda by bootstrapping, as done by Li et al. (2011). We calculated 400 bootstrap estimates, each of them obtained by resampling the data set with random replacement. For each iteration we calculated the regression coefficient, the survival-growth and fecundity functions, the kernel, and $\lambda_{\mathrm{t}}$. The $95 \% \mathrm{Cl}$ for $\lambda_{\mathrm{t}}$ was derived from the frequency distribution of these values. All analyses were conducted using IPMpack (Metcalf et al., 2014) and Popbio (Stubben \& Milligan, 2007) packages in the statistical software $R$, version 3.2.1 (R Development Core Team, 2015).

\section{Management Scenarios}

We modeled the fate of the palm populations in forest fragments under two scenarios. We performed these simulations by changing the values in the survival-growth matrix according to each case. In the first scenario, we modeled the removal of individuals in different proportions (5\%, 10\%, 20\%), simulating the effect of actions taken by the landowners, who often kill the palms or allow the free entry of cattle into the palm stands. In the second scenario, we modeled management consisting in the protection of seedlings from trampling, and in planting new seedlings; this simulation was made by increasing seedling survival and growth in different proportions (5\%,10\%). We analyzed changes in population size and leaf production in the model over the next 20 years.

\section{RESULTS}

\section{Population structure}

Population structure of $A$. malybo in the six forest fragments near Chimichagua showed very different trends. Two relics (4 and 6) did not have seedlings, and in two other ( 1 and 2 ) there were fewer seedlings than adults (figure 1); only in two relics (3 and 5) was the proportion of seedlings greater than that of adults; the latter relics have a continuous canopy cover (table 1). There were no juveniles in relic 2, and all other fragments their number was lower than that adults (figure 2). Overage density among all the relicts was 245 (S.D. $=135, \mathrm{n}=6$ ); the highest density was found in relics 3 and 5 , which had a continuous canopy cover, and harbored 320 and 460 palms/ha, respectively.

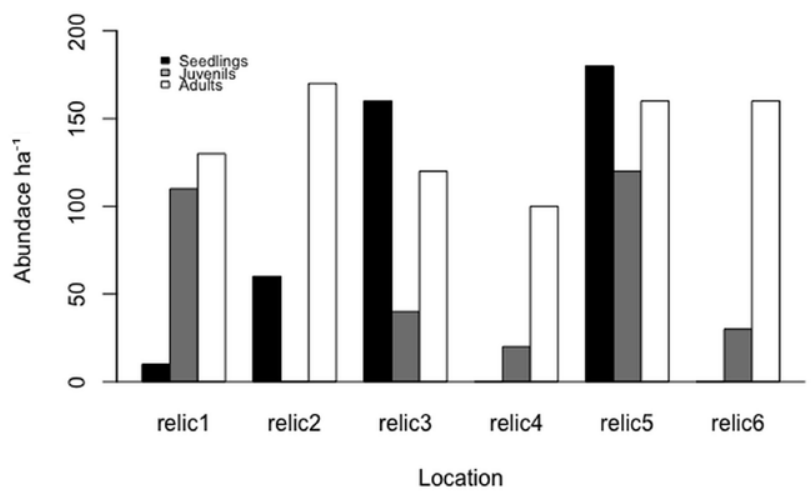

Figure 1. Population structure of Astrocaryum malybo in six forest relics near Chimichagua, Cesar, northern Colombia. 

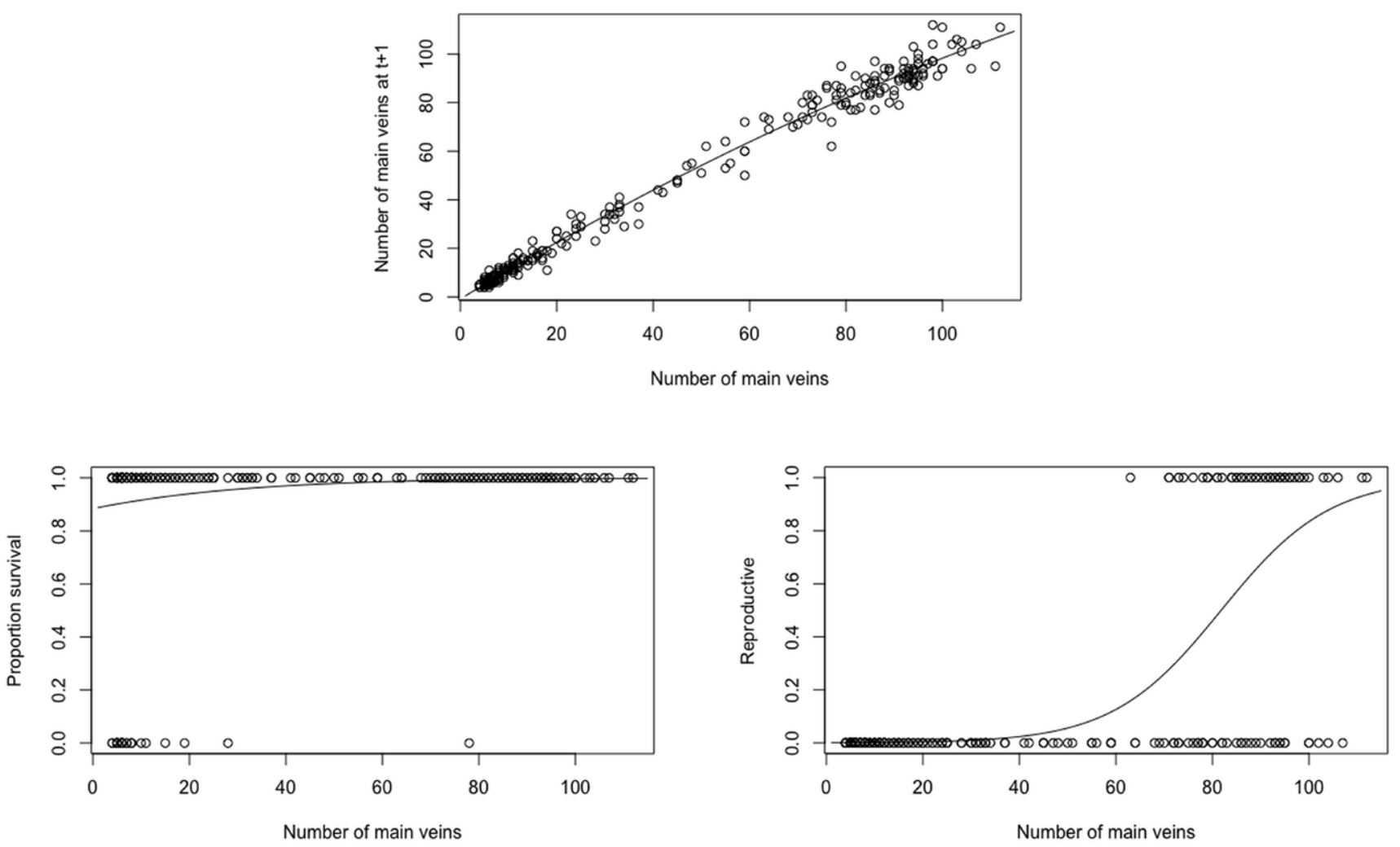

Figure 2. Relation of size (number of main veins in the youngest leaf) to growth (a), survival (b), and reproduction (c) in Astrocaryum malybo, near Chimichagua, Cesar, northern Colombia.

\section{Demographic parameters}

Size of $A$. malybo, as defined by the number of main veins in the youngest leaf, ranged between 4 veins in the first seedling leaf and 112 in adult palms. As shown in figure $2 a$, increase in the number of veins is constant during the juvenile stages; in adults, however, vein increase tends to be lower in older individuals. Similarly, survival of individuals is related to their size, with seedlings and young juveniles being less likely to survive than adults (figure 2b). Reproduction was also related to size, increasing as individuals grow (figure 2c). The first reproduction was observed in individuals with about 63 main veins.

Age estimates (table 2) indicated that at our study site $A$. malybo passes 8 years in the seedling stage, 24 years in the juvenile stage, and begins to develop reproductive structures when the palm is 32 years old. After this time, the palm can survive for at least another 32 years, although it probably lives for more than 100 years.

\section{Results of modeling}

Transient dynamics simulations on the IPM show that the population of $A$. malybo would grow for the next 20 years, with a growth rate of 1.07084 (Cl 1.07078-1.07090). Under the scenario of removing individuals of any size class, the population grows for the first two or three years, then remains steady, and finally decreases (figure $3 \mathrm{a}$ ). When $5 \%$ of the individuals are removed (i.e. 17 individuals of any size per ha per year), population growth ceases for the next 20 years; when $10 \%$ or $20 \%$ of the individuals are removed, the population decreases, with a trend to disappearing within the 20 next years (figure 3a). On the other hand, our simulations show that any increase in seedling 
Table 2. Leaf production, growth and estimated age of Astrocaryum malybo near Chimichagua, Cesar, northern Colombia.

\begin{tabular}{cccccc}
\hline $\begin{array}{c}\text { Size } \\
\text { category }\end{array}$ & $\begin{array}{c}\text { Leaf production rate } \\
\text { (leaves/year) }\end{array}$ & $\begin{array}{c}\text { Vein increase rate (veins/ } \\
\text { year) }\end{array}$ & Interval & $\begin{array}{c}\text { Category } \\
\text { duration (years) }\end{array}$ & $\begin{array}{c}\text { Final age } \\
\text { (years) }\end{array}$ \\
\hline Seedlings & $1.83($ S.D. $=0.77, \mathrm{n}=157)$ & $0.59($ S.D. $=1.28, \mathrm{n}=154)$ & 8 veins & 13.56 & 13.56 \\
Juveniles & $1.94($ S.D. $=0.61, \mathrm{n}=64)$ & 2.10 (S.D. $=3.92, \mathrm{n}=61)$ & 48 veins & 22.86 & 36.42 \\
Adults & 2.27 (S.D. $=0.67, \mathrm{n}=102)$ & $1.11($ S.D. $=4.92, \mathrm{n}=98)$ & 52 veins & 46.85 & 83.27 \\
\hline
\end{tabular}

growth or survival would lead to population growth within the next 20 years (figure $3 b$ ).

The studied population of $A$. malybo produces ca. 35 spear leaves/ha/year. This figure will increase in the coming 20 years, as the population itself is growing (figure 4). Our simulations show that spear leaf production would decrease dramatically as

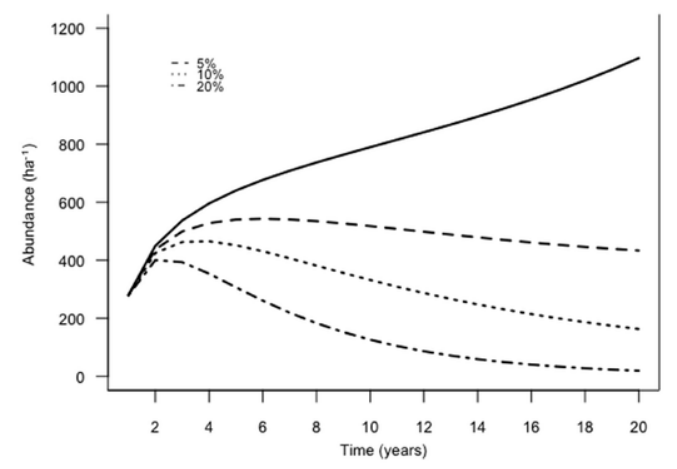

the percentage of palms removed increases. When more than $20 \%$ of the individuals (i.e. ca. $60-70$ palms of any size) are removed, spear leaf production would cease altogether after 12-14 years. On the other hand, a simulated increase of seedling growth/survival, whatever the proportion, would not still increase spear leaf production within 20 years.

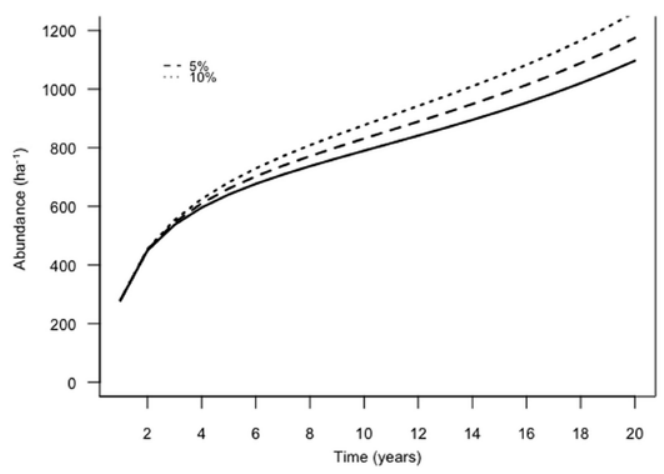

Figure 3. Projected abundance of Astrocaryum malybo in the next 20 years under the observed conditions (solid line) and under two scenarios: (a) removal of $5 \%, 10 \%$ y $20 \%$ of the individuals; (b) Increase of seedling survival and growth by $5 \%$ and $10 \%$.
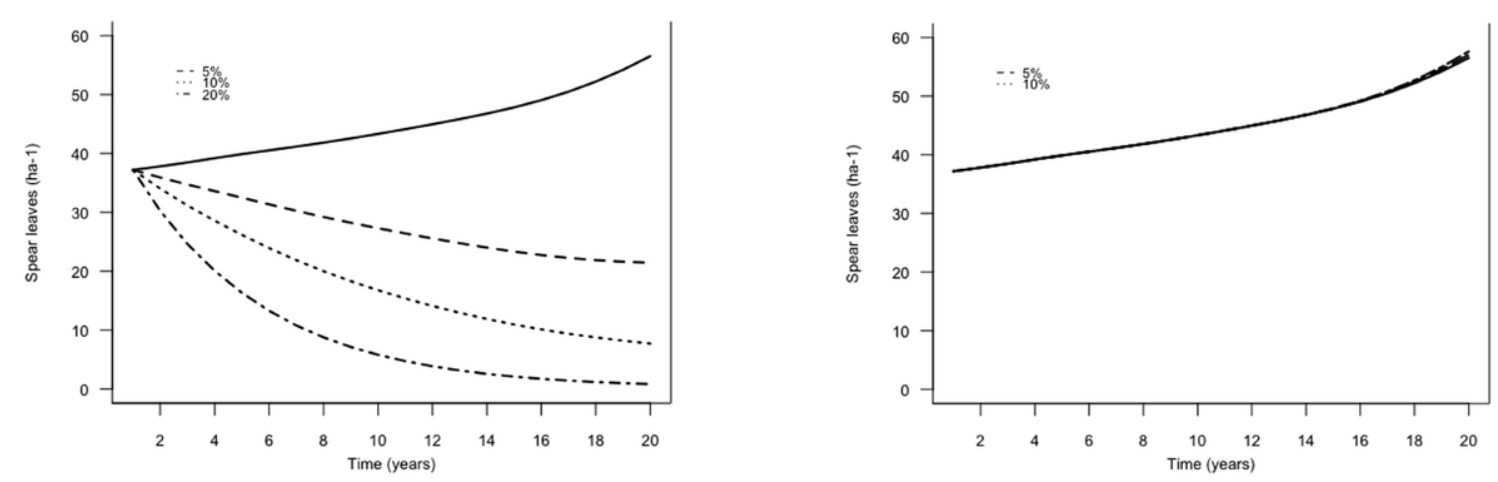

Figure 4. Spear leaf production of Astrocaryum malybo, projected under the observed conditions (solid line) and under two hypothetical scenarios: (a) removal of 5\%,10\%, or $20 \%$ of the individuals in any size class; (b) $5 \%$ and $10 \%$ increase in seedling growth or survival. 


\section{DISCUSSION}

The short period of observations of the studied population (one year) might affect estimation of vital rates, for example, adult mortality. This is a common shortcoming in the study of long-lived plants, but there are good reasons to think that it does not affect our conclusions. First, population studies in other Astrocaryum species have shown that vital rates do not differ significantly between consecutive years (García et al., 2016). Additionally, a population study of Chamaedorea radicalis showed that the trends found in two years did not differ substantially from those found in six years (Endress et al., 2006). Because of this, we consider that the described trends do represent the situation of $A s$ trocaryum malybo in the study area.

The demographic structure of populations has been used as an indicator of their conservation status and of the impact caused by the harvest of NTFP (Hall \& Bawa, 1993). A population including individuals in all size classes, with a predominance of seedlings and a progressive decrease in the proportion of individuals in higher classes, is considered to be well conserved and growing (Hall \& Bawa, 1993; Galeano et al., 2010). Under natural conditions, palm populations have been found to have this kind of structure (Galeano et al., 2010), and any deviations in the proportion of individuals per size class can be interpreted as the result of processes affecting the population (Thompson et al., 2009; Galeano et al., 2010; García et al., 2016; Andrade-Erazo \& Galeano, 2016).

Population structure of Astrocaryum malybo at all of our study plots shows alterations in the proportion of individuals throughout the size classes. In particular, there is a reduction in the proportion of seedlings or, in some cases, they are even missing altogether. This pattern, typical of populations with low regeneration, is probably related to the poor condition of the forest patches where the palm grows. The negative impact of cattle on seedling survival has been documented for another palm species in neighboring areas (Andrade-Erazo \& Galeano, 2016). The highest proportion of A. malybo seedlings in our plots (figure 1) was found in the two best-preserved forest relics near Chimichagua (table 1), where the vegetation still has a closed canopy. These plots had also the highest population growth rates, which supports the usefulness of structure as a proxy for population health in this species.

Although the studied population of $A$. malybo is growing at an annual rate of $7.1 \%$, which is much faster than that found in rain forest species of Astrocaryum (García et al., 2016), the annual death toll required to stop population growth (34 individuals/ ha) is relatively low. Death of seedlings by cattle trampling in the unprotected forest remnants could easily cause such toll.

Because of this, it does not seem recommendable to extract seedlings from the forest patches in order to establish plantations, as has been done in the past (García, 2013). Instead, it is advisable to collect ripe fruits from isolated adult palms standing in pastures, where there is no chance for seedlings to establish. These fruits should be spread in forest remnants, in order to increase seedling recruitment. On the other hand, seedlings and juveniles in forest patches should be protected from cattle trampling by isolating these areas from pastures, as our simulations show that even a small increase in seedling survival would lead to population growth within the next 20 years.

Conservation of forest remnants, which are often located among streams, will be directly beneficial to landowners as a means of preserving their water supplies, not to mention the fact that protecting such remnants is required by law. Because of this, it should not be difficult to promote awareness among landowners, even though many of them regard the fiercely armed $A$. malybo as a nuisance and a potential danger to cattle (García, 2013).

Because of the economic importance of the palm to landless peasants, it would be vital to reach some kind of agreement between harvesters, 
artisans, landowners, and environmental authorities, in order to manage these forest remnants as some sort of extractive reserves. This, together with the establishment of biological corridors between the largest forest fragments, would make an interesting integrated approach to conservation of dry forest species.

The observed spear leaf production, as well as that projected by our simulation, reveal that population of $A$. malybo in isolated forest remnants like the ones in our study keep a regular supply of fiber for handicraft production. The sustainability of this supply seems guaranteed, particularly as harvesters minimize damage to the palm by harvesting only the usable leaflets (García et al., 2011).

The dramatic fragmentation and severe reduction of dry forest areas in Colombia, as well as their scarce representation in the National System of Protected Areas, has led researchers to suggest that conservation efforts should focus on protecting forest remnants in private lands (Pizano \& García, 2014). Under this scenario, A. malybo is one of the most interesting species, particularly around the Zapatosa lagoon complex, in the Colombian Caribbean. The sustainable harvest of its spear leaves, the economic importance of handicraft production based on them, and the cultural significance of palm weaving, dating back to the Ette Ennaca or Chimila aboriginal people (Andrade, 2004), all combine to make this plant a key species for conservation of forest relicts. Furthermore, the endemic nature of the species in Colombia and its endangered status give this palm a charismatic appeal that should not be disregarded.

On the other hand, introduction of the species in agroforestry systems should be encouraged, in order both to increase fiber availability, and to reduce pressure on forest fragments. A combination of the species in agroforestry with its role as a key species for promoting protection of forest remnants can turn this palm from an endangered species into a tool for conservation of dry forest areas, and a source of income to local communities.

\section{CONCLUSIONS AND MANAGEMENT RECOMENDATIONS}

Populations of Astrocaryum malybo in Chimichagua, Cesar, grow in remnants of secondary vegetation along creeks. Under this environment, its population structure shows an alteration in the proportion of individuals per size class, in particular a reduction in the number of seedlings, which is typical of populations with low regeneration. Alterations in population structure are apparently related to the poor conditions of the forest relics, particularly the free access of cattle.

However, in the best-preserved plots with a continuous canopy, the population of A. malybo will grow at an annual rate of $7.1 \%$ over the next 20 years, providing up to 35 spear leaves/ha/year for handicraft production. Yet, any situation affecting the survival of individuals of any size can lead to a rapid decrease of population growth, bringing it to zero if 34 individuals of any size die per ha/yr. In contrast, any actions favoring seedling survival and growth would increase population growth rate, although the availability of spear leaves would not increase in the next 20 years, as individuals take a long time to be harvestable.

Our results show that natural regeneration of $A$. malybo near Chimichagua can be favored through management and protection of the forest remnants where it thrives. In this way, a supply of fiber for handicraft production can be maintained, while protecting this endangered species.

\section{ACKNOWLEDGMENTS}

We thank Osmelia Pedrozo, María Concepción Flores, Martín Mesa, and many other people in Chimichagua and El Banco, for sharing with us their knowledge on A. malybo. Field work was made under the projects Palm Harvest Impacts in Tropical Forests-PALMS (FP7-ENB-2007-1), and Estudios Ecológicos para el Manejo Sostenible de 
Palmas Útiles Colombianas-COLCIENCIAS (grant \# 110148925263).

\section{CONFLICT OF INTERESTS}

The author declares that he hasn't conflict of interest.

\section{CONTRIBUTION BY AUTHOR}

The sole author is responsible for the work in all aspects that led to the development of its publication.

\section{BIBLIOGRAPHIC REFERENCES}

Andrade, V. (2004). Componente de materias primas y planes de manejo. Guía para el manejo y aprovechamiento de la guadua -cultivo de mimbre-palma estera-mopa mopa o barniz de Pasto. Pasto: Artesanías de Colombia-Programa Nacional de Cadenas Productivas para el Sector Artesanal. $55 \mathrm{p}$.

Andrade-Erazo, V. \& Galeano, G. (2016). La palma amarga (Sabal mauritiiformis, Arecaceae) en sitios productivos del caribe colombiano: estudio de caso en Piojó, Atlántico. Acta Biológica Colombiana, 21(1), 141-150.

Barrera, V.A., Torres, M.C. \& Ramírez, D.S. (2007). Protocolo para la producción sostenible de artesanías en palma estera (Astrocaryum malybo) en el Cesar (Unpublished Report). Bogotá: Artesanías de Colombia S.A. 57 p.

Easterling, M.R., Ellner, S.P. \& Dixon, P.M. (2000). Size-specific sensitivity: applying a new structured population model. Ecology, 81(3), 694-708.

Endress B., Gorchov, D.L. \& Berry, E.J. (2006). Sustainability of a non-timber forest product: Effects of alternative leaf harvest practices over 6 years on yield and demography of the palm Chamaedorea radicalis. Forest Ecology and Management, 234, 181-191.

Estupiñán-González, A.C., Jiménez-Escobar, N.D., Cruz, M.P., Sánchez, N., Galeano G. \& Linares E.
(2011). Plantas útiles del complejo cenagoso Zapatosa. En: J.O. Rangel (ed.). Colombia diversidad biótica. Publicación especial No. 2. Guía de campo. Bogotá: Instituto de Ciencias Naturales, Universidad Nacional de Colombia, Corpocesar.

Galeano, G. \& Bernal, R. (2005). Palmas. En: E. Calderón, G. Galeano \& N. García (eds.). Libro rojo de plantas de Colombia. Volumen II: Palmas, frailejones y zamias (pp. 59-224). Bogotá: Instituto de Investigación de Recursos Biológicos Alexander von Humboldt, Instituto de Ciencias Naturales-Universidad Nacional de Colombia, Ministerio del Medio Ambiente.

Galeano, G. \& Bernal, R. (2010). Palmas de Colombia-guía de campo. Bogotá: Universidad Nacional de Colombia. 688 p.

Galeano, G., Bernal, R., Isaza, C., Navarro, J., García, N., Vallejo, M.I. \& Torres, C. (2010). Protocolo para evaluar la sostenibilidad del manejo de palmas. Ecología en Bolivia, 45, 85-101.

García, N. (2013). Palma estera (Astrocaryum malybo). En: R. Bernal \& G. Galeano (eds.). Cosechar sin destruir - Aprovechamiento sostenible de palmas colombianas (pp. 176-182). Bogotá: Facultad de Ciencias, Instituto de Ciencias Naturales, Universidad Nacional de Colombia.

García, N. Galeano, G., Bernal, R. \& I, H. (2013). Management of Astrocaryum standleyanum (Arecaceae) for handicraft production in Colombia. Ethnobotany, Research and Applications, 11, 85-101.

García, N. Torres, M.C., Bernal, R., Galeano, G., Valderrama, N. \& Barrera, V.A. (2011). Management of the spiny palm Astrocaryum malybo in Colombia for the production of mats. Palms, 55(4), 190-199.

García, N., Galeano, G., Mesa, L., Castaño, N., Balslev, H. \& Bernal, R. (2015). Management of the palm Astrocaryum chambira Burret (Arecaceae) in northwest Amazon. Acta Botánica Brasilica, 29(1), 45-57.

García, N., Zuidema, P.A., Galeano, G. \& Bernal, R. (2016). Demography and Sustainable Management of Two Fiber-producing Astrocaryum palms in Colombia. Biotropica, (Early View). DOI: 10.1111/ btp. 12338 
Groenendijk, P., Eshete, A., Sterck, F.J., Zuidema, P. \& Bongers, F. (2012). Limitations to sustainable frankincense production: blocked regeneration, high adult mortality and declining populations. Journal of Applied Ecology, 49, 164-173.

Hall, P \& Bawa, K. (1993). Methods to assess the impact of extraction of non-timber tropical forest products on plant populations. Economic Botany, 47(3), 234-247.

Instituto de Hidrología, Meteorología y Estudios Ambientales de Colombia (Ideam). (2015). Dataset from 2012-2013 of a pluviographic station from Chimichagua (Cesar), Colombia. Bogotá: Ideam.

Li, S.L., Yu, F.H., Werger, M.J.A., Dong, M. \& Zuidema, P. (2011). Habitat-specific demography across dune fixation stages in a semi-arid sandland: understanding the expansion, stabilization and decline of a dominant shrub. Journal of Ecology, 99, 610-620.

Linares, E.L., Galeano, G., García, N. \& Figueroa, Y. (2008). Fibras vegetales empleadas en artesanías en Colombia. Bogotá: Artesanías de Colombia S.A., Instituto de Ciencias Naturales de la Universidad Nacional de Colombia. 327 p.

Metcalf, C.J.E., McMahon, S.M., Salguero-Gomez, R., Jongejans, E. \& Merow C. (2014). IPMpack: An R package for demographic modeling with Integral Projection Models. R package version 2.1. https:// CRAN.R-project.org/package=IPMpack.

Pizano, C. \& García H. (2014). El Bosque Seco Tropical en Colombia. Bogotá: Instituto de Investigación de Recursos Biológicos Alexander von Humboldt $(\mathrm{IAvH}) .349$ p.

R Development Core Team. (2015). R: A language and environment for statistical computing. Vienna: R Foundation for Statistical Computing. ISBN: 3-900051-07-0, URL http://www.R-project.org.

Stubben, C.J. \& Milligan, B. (2007). Estimating and Analyzing Demographic Models Using the popbio Package in R. Journal of Statistical Software, 22(11).

Thompson, L.N., Moraes, M. \& Baudoin, M. (2009). Estructura poblacional de la palmera endémica Parajubaea torallyi (Mart.) Burret en zonas aprovechadas del Área Natural de Manejo Integrado El Palmar (Chuquisaca, Bolivia). Ecología en Bolivia, 44(1), 17-35.

Zuidema, P.A., Jongejans, E., Chien, P.D., During, H.J. \& Schieving, F. (2010). Integral Projection Model for trees: a new parameterization method and a validation of model output. Journal of Ecology, 98, 345-355. 